$11-1-2003$

\title{
On Treating A Survey Of Convenience Sample As A Simple Random Sample
}

W. Gregory Thatcher

University of West Florida, wthatcher@uwf.edu

J. Wanzer Drane

University of South Carolina

Follow this and additional works at: http://digitalcommons.wayne.edu/jmasm

Part of the Applied Statistics Commons, Social and Behavioral Sciences Commons, and the Statistical Theory Commons

\section{Recommended Citation}

Thatcher, W. Gregory and Drane, J. Wanzer (2003) "On Treating A Survey Of Convenience Sample As A Simple Random Sample," Journal of Modern Applied Statistical Methods: Vol. 2 : Iss. 2 , Article 21.

DOI: $10.22237 /$ jmasm/1067646060

Available at: http://digitalcommons.wayne.edu/jmasm/vol2/iss2/21

This Brief Report is brought to you for free and open access by the Open Access Journals at DigitalCommons@WayneState. It has been accepted for inclusion in Journal of Modern Applied Statistical Methods by an authorized editor of DigitalCommons@WayneState. 


\section{On Treating A Survey Of Convenience Sample As A Simple Random Sample}

\author{
W. Gregory Thatcher \\ Department of Health \\ University of West Florida
}

\author{
J. Wanzer Drane \\ Department of Epidemiology \& Biostatistics \\ University of South Carolina
}

Threat of bias has kept many from using data gathered in less than optimal conditions. We maintain that when convenience sampling represents race and gender at nearly correct proportions and can be beneficial, as these two variables are quite often used as stratification variables. We compared a convenience sample with a proven sample. Race and Sex were nearly proportional as was found in the proven sample. We conclude that the convenience sample can be used as though it is simple random.

Key words: Simple random sampling, convenience sampling

\section{Introduction}

From the first semester of Introduction to Statistics through our career as scientists by whatever names, we are warned of the sampling and non-sampling errors and how to overcome them. Recently a question was asked: "May I treat my convenience sample as a simple random sample?" To answer the question we employed a sample of known qualities, SCYRBS99, the South Carolina Youth Risk Behavior Survey of 1999.

Representative coverage of Gender and Race is paramount, if the sample is to be instructive when formulating health policy, and we know that SCYRBS99 and earlier YRBS samples are constructed so that the estimates of prevalence among these two variables, as well as others, are nearly unbiased (CDC, 1999).

If we can show that the estimates of the percentages of gender and race are nearly the same in the convenience sample as are in the

W. Gregory Thatcher, Department of Health, Leisure and Exercise Science. University of West Florida, 11000 University Parkway Pensacola, FL 32514. Phone: 850-474-2598, Fax: 850-474-2106. Email: wthatcher@uwf.edu weighted estimates of the YRBS sample of the same year, then we can at least increase our confidence in the treatment of our sample as simple random. Such a comparison does not, nor will it ever, PROVE the convenience sample to be totally unbiased and simple random, but it will go a long way toward our believing the prevalence calculated are nearly unbiased.

\section{Results}

The estimates of gender and race prevalence will be compared to those obtained from the SCYRBS99 sample, which are treated as population constants. Tables 1 and 2 display those values together with the estimates from the convenience sample.

Remembering that $\mathrm{X}^{2}$ is directly proportional to the sample size, which is 4421 in this case, then a Chi-square of 9.43 is not large at all. In order to reach a significance of only $0.05, \mathrm{~N}$ had to be at least $(4421 / 9.43) * 3.84)=$ 1800 . This is a case in which we have too much power. From an administrative point of view we would require alpha to be equivalent to about four standard errors or 0.0001 . Therefore, we are able to accept a difference of 46.66$44.36=2.30 \%$ as non-significant and administratively not important. Further, we can treat this sample as a simple random sample. 
Table 1: SCMS (Convenience Sample) with expected percentages and numbers obtained from SCYRBS99. Variable $=$ GENDER. Expected $\mathrm{F}=\mathrm{P}(\mathrm{F} \mid \mathrm{SCYRBS99}) * 4733 . \mathrm{X}^{2}=(2409-2376.91)^{2} / 2376.91$ $+(2324-2356.09)^{2} / 2356.09=0.87, \mathrm{df}=1, \mathrm{p}$-value $=0.35$.

$\begin{array}{ccc} & \text { SCMS } & \text { SCYRBS99 } \\ \text { GENDER } & \text { Percent } & \text { Percent } \\ & \text { Count } & \text { Expected number } \\ \text { F } & 50.90 & 50.22 \\ & 2409 & 2376.91 \\ \text { M } & 49.10 & 49.78 \\ & 2324 & 2356.09 \\ \text { Total } & 4733 & 4733\end{array}$

Table 2: SCMS (Convenience Sample) with expected percentages and numbers obtained from SCYRBS99. Variable $=$ RACE. Expected B $=\mathrm{P}(\mathrm{B} \mid$ SCYRBS99 $) * 4733 . \mathrm{X}^{2}=(1961-2022.41)^{2} / 2022.41+$ $(2460-2310.65)^{2} / 2310.65+(312-399.94)^{2} / 399.94=30.85 \mathrm{df}=2, \mathrm{p}$-value $=0.0000002$.

$\begin{array}{ccc} & \text { SCMS } & \text { SCYRBS99 } \\ \text { RACE } & \text { Percent } & \text { Percent } \\ & \text { Count } & 42.73 \\ \text { B } & 41.43 & 2022.41 \\ & 1961 & 48.82 \\ \mathrm{~W} & 51.98 & 2310.65 \\ & 2460 & 8.45 \\ \mathrm{O} & 6.59 & 399.94 \\ & 312 & 4733 \\ \text { Total } & 4733 & \end{array}$

Table 3: A repeat of Table 2 with the O category excluded. Expected $\mathrm{B}=\mathrm{P}(\mathrm{B} \mid \mathrm{SCYRBS99}) * 4421 . \mathrm{X}^{2}=$ $(1961-2062.84)^{2} / 2062.84+(2460-2358.16)^{2} / 2358.16=9.43, \mathrm{df}=1, \mathrm{p}$-value $=0.0021$.

$\begin{array}{ccc} & \text { SCMS } & \text { SCYRBS99 } \\ \text { RACE } & \text { Percent } & \text { Percent } \\ & \text { Count } & \text { Expected } \\ \text { B } & 44.36 & 46.66 \\ & 1961 & 2062.84 \\ \text { W } & 55.64 & 53.34 \\ & 2460 & 2358.16 \\ \text { Total } & 4421 & 4421\end{array}$


Between female and male distribution the convenience sample is right on target, but the $\mathrm{p}$-value of the chi-square among the three racial groups indicates a noticeable difference. An examination of actual count versus the expectations show there is an excess of white students at the expense of those captured as ' $\mathrm{O}$ ' or other than Black or White. If those are omitted, as usually is the case because of small numbers in more complex analyses, we have the results in Table 3 .

\section{Conclusion}

The convenience sample has nearly the same gender and racial compositions as is estimated from the SCYRBS99 data. It can then be treated as a simple random sample. For the skeptic or purist, caution should be used when generalizing across racial lines when using the SCMS data.
If stratification is made along the four categories (B,F), (B,M), (W,F) and (W,M), estimates within category should be nearly unbiased. From those four strata, comparisons could still be made without hesitation. If you insist on a larger alpha, then the RACE variable should not appear in a regression, linear or logistic, in conjunction with a set of risk and confounder variables.

\section{References}

Centers for Disease Control and Prevention. (1999). Division of Adolescent and School Health Youth Risk Behavior Survey, 1999. http://www.cdc.gov/nccdphp/dash/yrbs/ 